\title{
Transforming Bodies and Religions
}

This book sheds an interdisciplinary light on 'transforming bodies': bodies that have been subjected to, contributed to, or have resisted social transformations within religious or secular contexts in contemporary Europe. It explores the intersections of race, ethnicity, gender, sexuality, and religion that underpin embodied transformations. Using post-secularist, postcolonial, and gender/queer perspectives, it aims to gain a better understanding of the orchestrations and effects of larger social transitions related to religion.

This volume is the outcome of the intensive collaboration of the authors, who for years have been meeting regularly in Utrecht, the Netherlands, to discuss themes related to religion and 'the challenge of difference', with an added afterword by Prof. Pamela Klassen from the University of Toronto. The book is divided into three subsections that focus on particular types of embodiment: body politics in governmental and NGO organisations; the role of the body in literary and/or autobiographical narratives; and ethnographic case studies of bodies in daily life.

Doing so, it provides an innovative exploration of contemporary religion and the body. It will, therefore, be of great interest to scholars of Religious Studies, Gender and Sexuality Studies, Postcolonial Studies, Anthropology, Sociology, Theology, and Philosophy.

Mariecke van den Berg studied Theology (BA) and Gender Studies (RMA) at Utrecht University. She obtained her PhD in Public Administration in 2014 at the University of Twente. She currently works as a postdoctoral researcher at Utrecht University in the project Beyond 'Religion versus Emancipation': Gender and Sexuality in Women's Conversion to Judaism, Christianity and Islam in Contemporary Western Europe, funded by the Netherlands Organisation for Scientific Research (NWO). She is assistant managing editor at the open-access journal Religion and Gender.

Lieke L. Schrijvers is a $\mathrm{PhD}$ candidate for a joint doctorate at the Department of Philosophy and Religious Studies at Utrecht University and the Centre for Research on Culture and Gender at Ghent University. Her current research 
is a comparative ethnographic study of religion, gender, and sexuality among female converts in Jewish, Christian, and Muslim communities in the Netherlands. With this project, she is part of the NWO-funded project Beyond 'Religion versus Emancipation': Gender and Sexuality in Women's Conversion to Judaism, Christianity and Islam in Contemporary Western Europe.

Jelle $\mathrm{O}$. Wiering is a cultural anthropologist whose main interest lies in the field of religious studies. He is a lecturer in religious studies and sociology at the University of Groningen and Utrecht University. He recently finished his $\mathrm{PhD}$ at the University of Groningen. This project focused on the intersections of religion, secularity, and sexuality in the Netherlands. Previously, he researched Western Buddhists, and Dutch pilgrims traveling to Santiago de Compostela.

Anne-Marie Korte is a professor in religious studies at Utrecht University. She holds the chair of Religion and Gender, which aims to explore categories of gender, sexuality, and diversity when investigating the significance and operations of religion(s) in cultural processes and current social developments. She is currently Project Leader of the project Beyond 'Religion versus Emancipation': Gender and Sexuality in Women's Conversion to Judaism, Christianity and Islam in Contemporary Western Europe, funded by the Netherlands Organisation for Scientific Research (NWO), and was the founding director of the journal Religion and Gender. Korte's current research is directed at the role of gender and sexuality in contemporary accusations of blasphemy and on contemporary miracle stories. 
$\Longrightarrow$ Taylor \& Francis Taylor \& Francis Group http://taylorandfrancis.com 


\section{Routledge Critical Studies in Religion, Gender and Sexuality Series Editors: Ulrike E. Auga, Adriaan van Klinken, Anne-Marie Korte and Jeanette S. Jouili}

This book series is dedicated to the critical study of religion, gender and sexuality, in conversation and exchange with the broader qualitative social sciences and humanities. It publishes cutting-edge innovative research from both established scholars and up-and-coming researchers. Fundamentally concerned with "religion" as a field of imagination and power, the series explores the complex and dynamic relationship between religious knowledge, symbols and practices with categories of gender and sexuality in global contexts.

An Epistemology of Religion and Gender

Biopolitics, Performativity and Agency

Ulrike E. Auga

\section{Transforming Bodies and Religions}

Powers and Agencies in Europe

Edited by Mariecke van den Berg, Lieke L. Schrijvers, Jelle O. Wiering and Anne-Marie Korte

For more information and a full list of titles in the series, please visit: www. routledge.com/religion/series/RCSRGS 


\section{Transforming Bodies and Religions \\ Powers and Agencies in Europe}

Edited by Mariecke van den Berg, Lieke L. Schrijvers, Jelle O. Wiering, and Anne-Marie Korte

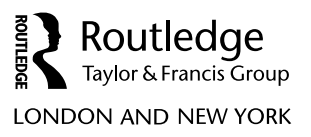


First published 2021

by Routledge

2 Park Square, Milton Park, Abingdon, Oxon OX14 4RN

and by Routledge

52 Vanderbilt Avenue, New York, NY 10017

Routledge is an imprint of the Taylor \& Francis Group, an informa business

(C) 2021 selection and editorial matter, Mariecke van den Berg, Lieke

L. Schrijvers, Jelle O. Wiering, and Anne-Marie Korte; individual

chapters, the contributors

The right of Mariecke van den Berg, Lieke L. Schrijvers, Jelle O.

Wiering, and Anne-Marie Korte to be identified as the authors

of the editorial material, and of the authors for their individual

chapters, has been asserted in accordance with sections 77 and 78 of the Copyright, Designs and Patents Act 1988.

All rights reserved. No part of this book may be reprinted or reproduced or utilised in any form or by any electronic, mechanical, or other means, now known or hereafter invented, including photocopying and recording, or in any information storage or retrieval system, without permission in writing from the publishers.

Trademark notice: Product or corporate names may be trademarks or registered trademarks, and are used only for identification and explanation without intent to infringe.

British Library Cataloguing-in-Publication Data

A catalogue record for this book is available from the British Library

Library of Congress Cataloging-in-Publication Data

A catalog record for this book has been requested

ISBN: 978-0-367-40728-5 (hbk)

ISBN: 978-0-367-80875-4 (ebk)

Typeset in Sabon

by Apex CoVantage, LLC 